\title{
Arthralgia in children: the epidemiological study
}

\author{
VA Malievskiy \\ From 18th Pediatric Rheumatology European Society (PReS) Congress \\ Bruges, Belgium. 14-18 September 2011
}

\section{Background}

Arthralgia is a frequent complaint of children, and it may be a symptom of arthritis and non-inflammatory diseases.

\section{Aim}

To determine the prevalence of joint pains in children of different ages.

\section{Methods}

Four towns and two rural districts of the Republic of Bashkortostan (Russia) were chosen for the questionnaire. The total number of the childhood population was 50442 children under 17 years of age. Totally 43907 children or their parents were examined with the help of the screening questionnaire. The parents were questioned by medical nurses during consulting reception hours, or in kindergartens, or at school. The children aged between 11 and 17 years answered the question list on their own. The screening questionnaire included two questions:

1. Did you observe any pain in joints of your child?

2. Did you observe any swelling in joints of your child?

Four variants of the answer were offered:

A - never happened, B - happened, but does not disturb for the last year, $\mathrm{C}$ - happened before and disturbs for the last year, D - happened for the last year.

\section{Results}

Complaints of arthralgia in the anamnesis or for the last year (answers B, C and D) were defined in 5490 children $(12.5 \%)$. The frequency of complaints of joint pains was higher in the girls (13.1\%), than in the boys $(11.9 \%$, $\mathrm{p}<0.001)$. More frequently (2562 children, $5.8 \%)$ the joint pains were marked earlier, but for the last year they did not disturb (answer B). In 1923 children

Correspondence: vmalievsky@mail.ru

Bashkir State Medical University, Ufa, Russia
(14.4\%) the pains happened in the past and happen for the last year (answer C), in 1005 children $(2.3 \%)$ the pains happened for the last year (answer D). The frequency of complaints of joint pains was $5.8 \%$ in the age between 4 and 6 years, and $13.3 \%$ in the age between 7 and 11 years, and $16.6 \%$ in the juvenile age (between 12 and 17 years of age).

754 children and/or their parents answered the question positively about the joint swelling (1.7 \%). 368 children and/or their parents indicated that the joint swelling had appeared or remained for the last year $(0.8 \%)$.

\section{Conclusion}

The frequency of complaints of joint pains was defined in $12.5 \%$ of the children. The prevalence of arthralgia was higher in the boys, than in the girls, and it increases with the age. Most children with joint pains did not suffer from the inflammatory joint disease.

Published: 14 September 2011

doi:10.1186/1546-0096-9-S1-P144

Cite this article as: Malievskiy: Arthralgia in children: the

epidemiological study. Pediatric Rheumatology 2011 9(Suppl 1):P144.

Submit your next manuscript to BioMed Central and take full advantage of:

- Convenient online submission

- Thorough peer review

- No space constraints or color figure charges

- Immediate publication on acceptance

- Inclusion in PubMed, CAS, Scopus and Google Scholar

- Research which is freely available for redistribution 